\title{
A Critical Discourse Analysis of EFL Learners' Post-reading Reflections in a Critical Literacy-based Class
}

\author{
Mei-yun $\mathrm{Ko}^{1}$ \\ ${ }^{1}$ Department of Applied Foreign Languages, National Formosa University, Taiwan \\ Correspondence: Mei-yun Ko, Department of Applied Foreign Languages, National Formosa University, 64 \\ Wun-hua Rd., Huwei, Yunlin, Taiwan. Tel: 886-5-631-5828. E-mail: mko@nfu.edu.tw
}

Received: June 13, 2013

Accepted: July 8, 2013

Online Published: July 10, 2013

doi:10.5430/elr.v2n2p1

URL: http://dx.doi.org/10.5430/elr.v2n2p1

\begin{abstract}
This study examined EFL learners' critical development in a critical literacy-based reading class by analyzing their reflective essays on three articles: one article they read before critical instruction and two after the instruction. The analytical framework was mainly based on Fairclough's (1992a) Three-Dimensional Model of Discourse, focusing on the dialectical relationship between the students' discursive practices presented in their reflections and their ideological social practices. Findings show that the students' development of critical consciousness was seen after the critical instruction because in their response to the pre-instruction reading article, almost all of the students reproduced the conservative motherhood discourse, assuming the taken-for-granted responsibilities of a wife and mother, while in their response to after-instruction reading articles, around one third of the students displayed egalitarian discourses that challenge the taken-for-granted ideas about gender differences and admit of diverse ways of being in this world, and liberatory discourses such as the adoption discourse that liberates infertile couples from the domination of the fertility discourse. Therefore, from this study we suggest that critical pedagogy be implemented in EFL language instruction to develop students' critical consciousness and help them to be active critical readers.
\end{abstract}

Keywords: Critical discourse analysis, Critical literacy, Critical pedagogy, English-as-a-foreign language

\section{Introduction}

Various approaches to second/foreign language teaching have been proposed over the past few decades, including Audio-Lingual Method, Communicative Language Teaching, Content-based Language Teaching, and Task-based Language Teaching, and the others. These approaches generally focus on how to teach language skills effectively and how to foster students' communicative competence, but they all fail to capture the social and political complexity of language and language learning (Okazaki, 2005). Language is not neutral; it is ideologically loaded. Any practice of language learning and teaching is intrinsically political and socially constructed (Auerbach, 1995, Pennycook, 1999). Advocates of critical literacy (e.g., Crookes \& Lehner, 1998; Morgan, 1998; Norton \& Toohey, 2004; Pennycook, 2001; Ramanathan, 2002) have proposed that critical pedagogy in second/foreign language teaching is necessary.

Based on critical pedagogy, the world is viewed as a text (Giroux, 1992). All the texts are ideological constructions embedded with discursive systems. They are the products of ideological and sociopolitical forces, and therefore must be constantly subjected to social critiques (Cervetti, Pardales, \& Damico, 2001). Language learners need to understand the social effects of texts and take a critical view to them to uncover the social inequalities and injustices imbedded in the texts and in this way they can transform themselves into critical agents and promote for a more equitable and democratic society.

Since the advocacy for critical pedagogy in second/foreign language education, critical literacy has been increasingly practiced in the field of English as a second language (ESL) education, while in the English as a foreign language (EFL) setting, not much has been attempted. In Taiwan, only several researchers/educators responded to the need for critical literacy in EFL education, including the empirical studies by Ko and Wang (2012a, 2012b), Kuo (2009), and Huang (2011a, 2011b). These studies all explored critical literacy implementation in a college EFL classroom, investigating students' critical written products and their views to critical literacy instruction. Similarly the present study also explored the implementation of critical literacy in a college-level EFL classroom, but focused on 
analyzing students' critical development through Critical Discourse Analysis (CDA) of their post-reading reflective essays on the texts that they read before critical literacy instruction and after the instruction. By so doing, it is hoped that the present study can add to the literature of critical literacy pedagogy in EFL contexts and contribute a better understanding of critical discourse analysis as an analytical framework.

The research questions the present study attempted to address are:

1. Can students' critical consciousness be developed in a critical literacy-based reading class?

2. What different discourses can be found in their reflections before and after the critical instruction?

As the present study employed a critical discourse analysis method, namely, Fairclough's Three-Dimensional model of discourse analysis, to analyze students' responses to the reading texts, the concepts of discourse, theoretical underpinnings of CDA and Fairclough's three-dimensional discourse model are reviewed below:

\section{Analytical Framework}

\subsection{Discourse}

Discourse is what James Paul Gee calls "language-in-use" (1999, p.1). Any instance use of language is never neutral. It is not only situated, that is, happening in a specific time and space, but also conditioned by what Gee (1990) termed Discourses, with a capital D, which he described as "ways of being in the world" or "form of life." He made the distinction between the small letter "discourses" and the capital letter "Discourses," showing how a language user's linguistic discourses are unconsciously shaped by the non-linguistic Discourses (forms of life). To quote Gee's own words:

[W]e, as 'applied linguists' or 'sociolinguists,' are interested in how language is used 'on site' to enact activities and identities. Such language-in-use, I will call 'discourse' with a 'little d.' When 'little d' discourse (language-in-use ) is melded integrally with non-language 'stuff' to enact specific identities and activities, then, I say that 'big D' Discourses are involved. ... In turn, you produce, reproduce, sustain, and transform a given 'form of life' or Discourse. All life for all of us is just a patchwork of thoughts, words, objects, events, actions, and interpretations in Discourses (1999, p. 7).

\subsection{Critical Discourse Analysis (CDA)}

For critical theoretical underpinnings, $\mathrm{CDA}$ is largely derived from the neo-Marxist tradition; and for an anti-foundationalist epistemological stance, CDA draws on social constructionism (Jorgensen \& Philips, 2002). On one hand, Neo-Marxism provides CDA with a powerful analytical tool to uncover the ideological effects of social injustice because it moves away from the economic determinism of classical Marxism and emphasizes cultural dimensions of social life, seeing domination and exploitation as culturally and ideologically established and maintained. On the other hand, $\mathrm{CDA}$ draws on social constructionism that views realities as socio-culturally constructed and therefore contingent, thus creating the freedom of agency to resist the determinism of structure or dominant ideologies. There are three important concepts that underpin CDA: dialectical relationship, ideology, and hegemony.

\subsubsection{Dialectical Relationship.}

Crucial to CDA is the dialectical relationships between discursive practices and social practices (Sunderland, 2004). Unlike radical discourse analysts who argue complete constitution of social reality in discourse, critical discourse analysts holding dialectical relationships recognize both the delimiting power of social institution and at the same time the shaping power of discourse; thus, it occupies the middle ground in the continuum of discourse's constructing power of the world, as shown in Figure 1.

Discourse is constitutive Dialectical relationship Discourse is constituted

Critical discourse analysis

Figure 1. The Role of Discourse in the Constitution of the World (Jorgensen \& Philips, 2002, p.20) 


\subsubsection{Ideology}

Unlike traditional Marxists who have treated ideology as an abstract system of values that binds people together and secures the coherence of the social order, critical discourse analysts view ideology as "a practice that operates in processes of meaning production in everyday life, whereby meaning is mobilized in order to maintain relations of power"(Jorgensen \& Philips, 2002, p. 75). Partially drawing on Althusser's theory of ideology (1971), critical discourse analysts admit that ideologies as social practices in social institution have the power to position people as social "subject" in particular way. They reject parts of Althusser's theory of ideology because it treats people as passive ideological subjects, over-emphasizing social structure while underestimating human agency. As shown in Figure 1, CDA argues for a middle ground between social structure and human agency. In Faiclough's (1992b) words, "subjects are ideologically positioned, but they are also capable of acting creatively to make their own connections between the diverse practices and ideologies to which they are exposed and to structure positioning practices and structures"( p.91).

\subsubsection{Hegemony}

The theory of hegemony comes from Antonio Gramsci, who argues that the hegemony of the dominant social class depends on winning the consent of the majority to existing social arrangements. Therefore hegemonies are products of negotiation of meaning in which all social groups participate (Gramsci, 1991). In other words, hegemonies depend on social consensus and are sustained ideologically in the "common sense" assumptions of everyday life. Because Gramsci's theory of hegemony ascribes a degree of agency to all social groups in the production and negotiation of meaning, it provides CDA a theoretical underpinning for arguing people as "agents of discursive and cultural change"(Jorgensen \& Philips, 2002, p. 17).

\subsection{Fairclough's Three-Dimensional Model of Discourse}

Fairclough (1992a) announced five theoretical propositions for CDA ( pp. 8-12):

- Language use - discourse - shapes and is shaped by society. In other words, discourse and society are in a dialectical relationship.

- Discourse helps to contribute (and change) knowledge and its objects, social relations, and social identity.

- Discourse is shaped by relations of power, and invested with ideologies.

- The shaping of discourse is a stake in power struggles.

- Critical language study sets out to show how society and discourse shape each other.

These five propositions stem from the two assumptions about language use; that is, language is both socially constitutive and socially determined. The implications of the assumptions for teaching are as follows: (1) teachers of critical literacy should work with students to develop a language of critique to analyze those latent interests and ideologies that work to socialize students in a way compatible with the dominant culture; (2) egalitarian discourses can have the potential to effect the desirable social change (Fairclough, 1992a).

Fairclough's model of critical discourse analysis is influenced by Halliday's functional linguistics. Halliday views every text as having three functions: ideational function, interpersonal function, and textual function (1978). A text has an "ideational" function through its representation of the world, an "interpersonal" function through social interactions between participants in discourse, and a "textual" function through uniting separate components into a meaning whole and combining this with a situational context. Likewise, Fairclough (1992a) views any discursive event, or any instance of language use, as having three dimensions: text, interaction, and context. Text here can be expanded to semiosis, which is meaning-making through language, body language, visual images, or any other way of signifying. Text is also "an interaction between people, involving process of producing and interpreting the text, and it is part of a piece of social action - and in some cases virtually the whole of it" (Fairclough, 1992a, p. 10). In other words, an interpretation of a text is the individual's interaction with the text, which is part of social action or context. The context here refers to social conditions of production/interpretation, or order of discourse - "totality of discursive practices of an institution and relationships between them" (Fairclough, 1992b, p. 138).

Corresponding to the three dimensions of discourse, critical analysis also has three dimensions: description of the text, interpretation of the interaction processes, and explanation of how the interaction process relates to context, as shown in Figure 2: 


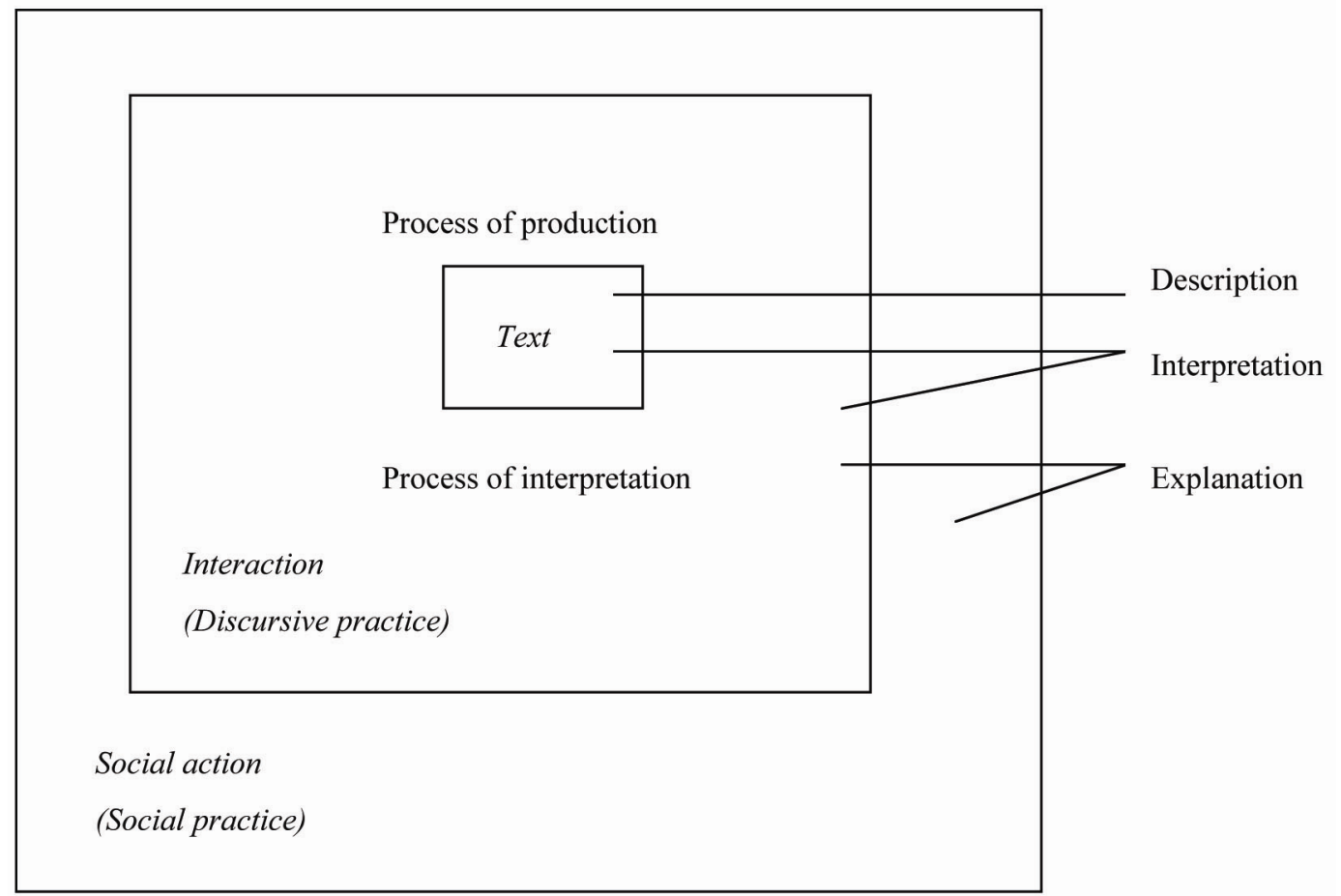

Figure 2. Fairclough's Three Dimensional Model of Discourse (Fairclough, 1992a, p.10)

For the present study, students' reflective essays were regarded as students' discursive practice in which they both consumed the text, namely, the in-class reading articles, and then produced the text, namely, their reflective essays. Therefore, students' reflective essays comprised the two dimensions of a discourse in Fairclough's model: text and discursive practice. The corresponding analytical tools are description for the text and interpretation for the discursive practice. In a critical discourse analysis, students' discursive practice, i.e., the discourses in their reflections were to be explained by the social practice which embodies a given ideology or ideologies, namely, the third dimension of a discourse. To simplify Fairclough's concepts, the first two dimensions were called "discourse" and the third dimension "society." The focus of the analysis was therefore on the dialectical relationship between discourse and society.

\section{Methods}

\subsection{Setting and Participants}

Participants were 39 English-major students enrolling in an English Reading class at a university in Taiwan where a critical literacy approach was implemented (for a detailed account of the critical literacy teaching, see Ko, 2013). All of the students were required to hand in a reflective essay on each reading article that had been discussed in class.

\subsection{Data Collection and Analysis Procedure}

Data were collected from three in-class reading articles and students' post-reading reflections on them, 117 pieces in total. The three reading articles included "Mother's Camp," an article they read prior to the critical literacy instruction, and "Families Grow Less Traditional" and "Eight Is Too Many," which they reflected on after critical literacy instruction.

The analysis procedure, similar to that in Ko and Wang's study (2012b), was as follows: I first read through the three reading articles and identified salient discourses in each of them. Then I proceeded to read students' reflective essays piece by piece carefully. When a discourse was spotted, it was labeled and marked in the margin of the essays. I continued in this way several times until all the discourses were identified and labeled or re-labeled. Finally, one or two representative excerpts for each identified discourse was analyzed to explain how the discourse presented in their reflections was shaped by certain ideologies in their social practices, and at the same time how it could also shape the social practice by creating a new discourse, different from the old or taken-for-granted one, which in turn shapes a new/changed social practice. 


\section{Interpretation and Findings}

\section{1 "Mother's Camp" and Students' Reflections}

"Mother's Camp" is a very short article the course teacher gave his students to read in the first week, i.e., before the critical instruction. The teacher asked them to read it in five minutes and then to write down their responses to this short article. In other words, "Mother's Camp" is an article the students read and reflected on before the critical literacy-oriented instruction began.

The most obvious discourse identified in the reading article, "Mother's Camp," is what we may term "motherhood discourse." The motherhood discourse prescribes what an ideal mother should do in a traditional, male-dominated society. In a traditional society, a mother is constructed as a house keeper whose job is to take care of her husband and children, and also to do all the housework. Because mothers work so hard to keep a comfortable home for their husband and kids that they deserve a getaway, mother's camp is their ideal getaway where each mother has a room to herself.

The idea of a mother's having "a room to herself" echoes a feminist discourse, but the whole article is underpinned by the conservative discourse of motherhood. Related to the motherhood discourse is the gender differences discourse as shown in the representation of housework in the article:

Many of their husbands say they want to help. But then they burn the rice or they can't find the pans. They ask so many questions that their wives decide it is easier to do the job themselves. ("Mother's Camp")

The gender differences discourse holds that women are expected to be better than men in certain things such as cooking, house keeping, and child rearing. It is expressed in such English proverbs as "a woman's place is in the home." On the other hand, men are expected to work outside and earn money for the family. It is clear that the gender differences discourse underpins the conventional idea of the mother's role prescribed in the motherhood discourse.

A critical discourse analysis of students' responses to this text showed that most of the students reproduced the conservative motherhood discourse and articulated an "it's-not-easy-being-a mother discourse," showing how hard mothers have worked for their families and they certainly deserve a getaway to refresh themselves. Figure 3 shows the discourses articulated in most students' responses to the short article "Mother's Camp."

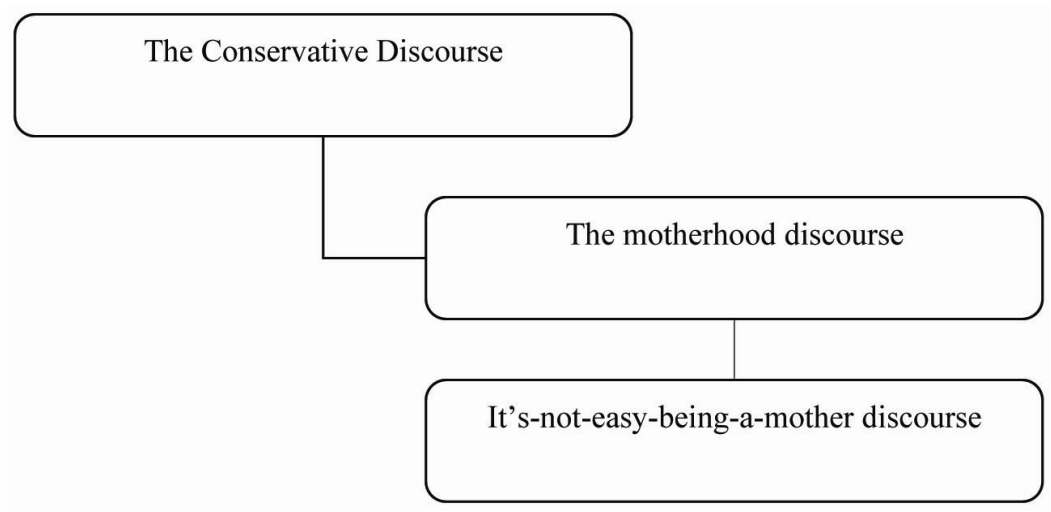

Figure 3. Discourses in Students' Reflections on "Mother's Camp"

Below is one example in the students' reflections that reproduced the motherhood discourse by assuming the taken-for-granted responsibilities of a wife and mother, i.e. housework and the caring for husband and kids. Mother's Camp is only a pleasant but temporary escape from these responsibilities.

In my opinion, Mother's Camp is a great place for women especially working women to escape the responsibilities of being a wife and mother. They just enjoy beautiful scenery, warm, sunny weather and get massages. I think it's significant for women working full time. By going to Mother's Camp, they release stress and have their own free time and personal space. They don't have to do much housework as usual. (S7, reflection)

Only one student produced an egalitarian discourse resisting the gender stereotyping implied in the motherhood discourse.

It is quite unbelievable for me to read that most working mothers still have to take care of their husbands and children after work. In my opinion, men and women are equal and they should take responsibility of their 
families together, including doing chores or laundry. Taking a vacation as the women did in this article is not a final solution. (S22, reflection)

This student's reflection articulated an oppositional discourse against the conservative discourse of motherhood, and was the only one to do so.

\section{2 "Families Grow Less Traditional" and Student Reflections}

The reading article "Families Grow Less Traditional" is a news story selected from the New York Times. It reports new directions in the North American family and examines the different responsibilities of fathers and mothers and the effects of these changes on the lives of children. There are two obvious discourses detected in this news story: one is the traditional-families-as-norm discourse and the other is the egalitarian discourse. The traditional-families-as-norm discourse perpetuates the taken-for-granted concepts of a traditional family. The egalitarian discourse admits of less traditional families such as gay/lesbian families, single-parent families, or families with test-tube babies.

Corresponding to the discourses detected in the news story "Families Grow Less Traditional," the discourses in students' reflections can also be classified under two umbrella discourses which we designate as "conservative discourse" and "egalitarian discourse' respectively. The conservative discourse privileges traditional families as the norm, emphasizing the status quo and hence disapproving of other ways of being in the world such as gay families. Opposite to the conservative discourse, the egalitarian discourse eschews the totalizing and monolithic discourse in the conservative discourse by welcoming the idea of diversity, and hence admits of different ways of being in this world.

Under the category of conservative discourse, we can also detect three subcategories of related discourses in students' reflective essays, namely, the traditional-families-as-norm discourse, the gender differences discourse, and the heterosexuality discourse. Similarly, under the category of egalitarian discourse, we can map out two related discourses in students' reflective essays: the equality discourse and the diversity discourse. Figure 4 shows the discourses categorized from analysis of students' reflective essays on "Families Grow Less Traditional."

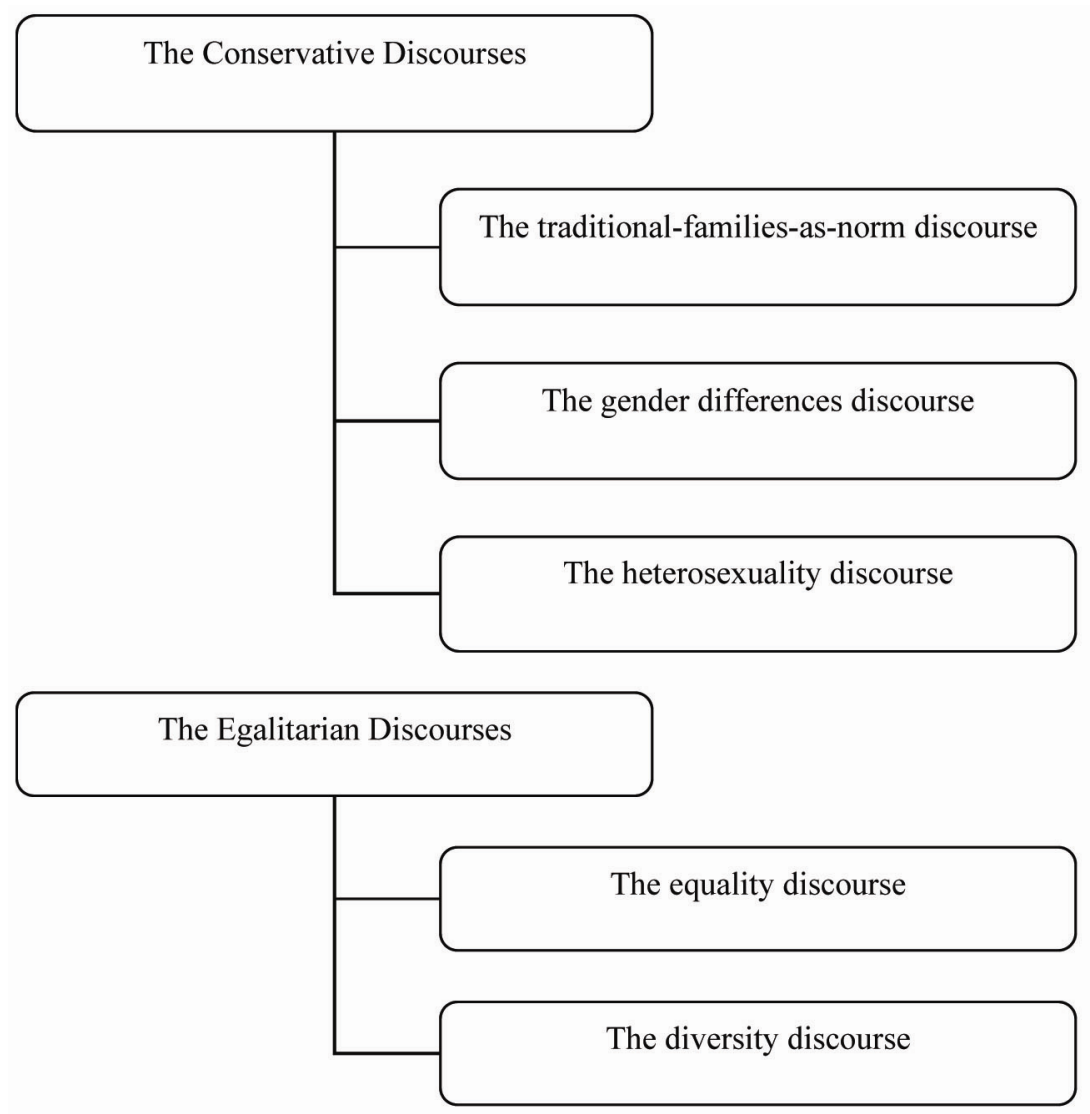

Figure 4. Discourses in Students' Reflections on "Families Grow Less Traditional" 


\subsubsection{Conservative Discourse}

(1) The traditional-families-as-norm discourse.

Many students in this class admitted that it was social changes that led to less traditional families. However, they still yearn for the happiness in traditional families in their minds, believing traditional families to be normal and the way things ought to be:

After school, children went home, did the homework, and played with their cousins at courtyard. Grandparents sat on the rockers and felt sleepy. Aunts, uncles, and parents sat on the benches or the stools and chatted about recent lives. At dinner, all of the family sat around table, chatted and ate happily. This is a picture of traditional family that everyone lives together, feel free, peaceful and less stress. (S11, reflection)

This student reflection depicts a traditional rural family in Taiwan, where there is little change in people's ways of living. It is also a picture of the extended family where three generations live under the same roof. Another student reflection expresses a yearning for traditional families which she believed to be the correct way of life:

Sometimes we thought that traditional rules bind us so much, but it actually binds some moral grounds that we really should have. With tradition, parents should take care of their children more cautious in their educational way and life style. (S18, reflection)

Such traditional-families-as-norm discourse in student reflections indicates a naturalized or taken-for-granted concept of what a family should be in Taiwanese society. Traditions pass from one generation to another and therefore are honored by time. In these students' minds, what is sanctioned in traditions must be right, or how things ought to be, and therefore moral. This discourse certainly makes it difficult for them to accept other social practices such as "single-parent family" or "gay family" because it will not provide a good example for children's education.

(2) The gender differences discourse.

The traditional-families-as-norm discourses actually stem from the other two related discourses: the heterosexuality discourse and the gender differences discourse. Deeply rooted in these two discourses is the concept that there are the differences between a male and a female and that they have different roles to play. Because of the time-honored concepts of heterosexuality and gender differences, some students found it difficult to accept the idea of gay families or single-parent families.

The gender differences discourse is found in several students' reflections when they consider what role(s) a male or a female should play in a family:

Sometimes I do not want to get married, because I want much free time. If I get married, I should spend much time to take care the children and family. . . And I also think that teaching children is very difficult for me. I do not have much patience. Now, I will try to make myself more patience and have fun with child. (S13, reflection)

This female student is reproducing here the traditional idea that women should be in charge of household work while men should earn bread for the family. A woman is thus represented as a patient mother sacrificing all her time and pleasures to rear children. This discourse, however, is in conflict with another discourse in her reflection, that is, the celibacy discourse: "Sometimes I do not want to get married, because I want much free time." The gender differences discourse is found in another student's reflection:

I believe that a man/husband is busy and lucky in the world because they are only responsible for making money for himself/his family. This is a reason for them to escape child care though the situation is ameliorating slowly. (S24, reflection)

Although this student is aware of the social changes that child caring is not necessarily the females' responsibility, as when she says "the situation is ameliorating slowly," she is still clinging to the old concept about gender differences that a wife's place in the home while the husband's job is to earn money for the family.

(3) The heterosexuality discourse.

The gender differences discourse easily leads to the heterosexuality discourse in which only love between different sexes is to be blessed while love between the same sex is considered to be, if not anathema, at least an unnatural act which will not be sanctioned by most people or win support in society. Many of the students when expressing their views on gay families reproduced this kind of heterosexuality discourse:

Since the democracy has established, more and more people fight for their freedom and rights, and they do have the rights to do what they want. However, it may cause some problems like the children in the gay families do not know why they have two Daddies or two Mommies, or the children in the single families may feel lonely because their lack of the other parent's love. It is not saying that democracy is an error. In my 
opinion, the natural of democracy is good, but people have to follow the rules not only in the society but also in their hearts. (S9, reflection)

In this student's reflection, it is not difficult to detect the discourse of heterosexuality-as-norm. Because of this, she thinks gay families or single-parent families are causing problems for their offspring. One corollary of such a discourse is a totalitarian mindset that people should follow rules in the society so that a stable social order can be maintained. Students reproducing the heterosexuality discourse will give support to a conservative ideology that values the status quo and resists any social change. The following student reflection shows this kind of ideology when he is stating his reasons against gay families:

Gay parents also appear in this generation. Some countries allow gay parents to adopt children. However, in my opinion, it may make the society disorderly and children themselves will confuse their parents' gender. Perhaps children will be mock at about their families. Although there is no question for gay lovers to fall in love, the child adopting problems for them must be considered and propose a better solution for them to have children. (S10, reflection)

Although this student admits gay people as an undeniable given in our society and in a way touches on an egalitarian discourse that fights for gay people's right, he is still reproducing the heterosexuality-as-norm discourse by foregrounding the idea that gay parents will disrupt a harmonious society constructed in the hegemonic ideologies of traditional families and gender differences.

\subsubsection{Egalitarian Discourse}

(1) The equality discourse

The equality discourse is a reaction against the gender differences discourse because it challenges the traditional and taken-for-granted idea about gender differences, which in many ways privileges men over women. Therefore, the equality discourse raises students' consciousness about gender stereotyping entrenched in traditional families:

When it comes to family, the traditional gender stereotypes also rule. "Housewife' is still regarded as women's primary role. They are taught to be quiet, tender, and ignorant. Their final goal is to build up a perfect family - which means that they have to take responsibility of doing chores, fostering children and attending the needs of husband. On the other hand, a woman without a family-no matter how successful she has achieved in work - is still deemed as failure that disobeys her assigned vocation. (S28, reflection)

In this student's reflection we can see that she is contesting the gender stereotyping in traditional families. There are two taken-for-granted storylines about women which are socio-culturally constructed, or "taught." Also, women are expected to marry themselves off and bear their husbands children. If they don't, they are "deemed as failure that disobeys her assigned vocation." When students call these gender stereotypes into question, they begin to challenge these naturalized concepts of discourses. Such equality discourse as a counter-discourse against the taken-for-granted one is very important in a student's development of critical literacy because it raises his/her consciousness of possible social inequalities implied in stereotyping. Consciousness-raising is also found in several students' reflections on gay families. In the reflection below, we found the student was articulating counter-discourses which fought for the gay rights and in the meantime challenged implicitly the dominance of heterosexuality:

Moreover, although there is a great deal of homosexual couples they are not allowed to adopt a kid in Taiwan. Supposed they do adopt a kid, a numerous difficulties ensue. I have some lesbian and gay friends. They have been living pretty hard. They cannot tell the truth to their families, and so they have been pushed toward marriage with heterosexual. Some of my friends said they will give way to a heterosexual marriage, because it is harsh to live as homosexual couples in Taiwan. I truly hope that homosexual couples in Taiwan can one day be treated like normal parents like in USA and can receive supports from others. (S32, reflection)

(2) The diversity discourse

The diversity discourse can be regarded as a counter-discourse against the traditional-families-as-norm discourse. It calls into question the taken-for-granted idea that traditional families are the norm. In one student's reflection he challenged the time-honored conception of traditional family because there exist in our society today so many different family structures and the so-called "traditional family" is actually "less common than most other types in the society;" therefore, the functions of the different families are more important than their forms:

Perhaps there are still people tend to promote the traditional family as the norm. However, in my opinion, that the so-called "traditional family" is less common than most other types in the society. In this case, the main point we have to understand is that what the family provides for its members is more important than the way it is structured. (S20, reflection) 
The diversity discourse sets up the necessary mindset for accepting social transformation. One student produced in her reflection an open-minded discourse welcoming diversity and change:

Although there are many changes from twenty years ago to now, there are not exactly so bad. If we could open our mind to accept those changes or to find out the better way to improve the changes, then the modern life would be much better. (S29, reflection)

\section{3 "Eight Is Too Many" and Student Reflections}

The reading article "Eight Is Too Many" is a news story selected from The New Republic. It explores the problems of multiple births: its media representation, the misuse of fertility technology, and the potential problems families of multiple births face in raising them, which include health/medical problems, financial problems and educational problems. The article also offers a solution to the problem of multiple births. Structurally, the article is a typical problem-solution text.

There are two obvious discourses spotted in this reading article: the fertility discourse and the media representation discourse. Each discourse has its related discourses and forms a network of discourses. The fertility discourse is related to the biological son discourse and the fertility technology discourse, which is the technological intervention to enable biological offspring for infertile couples. The media representation/effect discourse is a critical awareness of the ways in which representation in the media influence their viewers.

Corresponding to the discourses spotted in this reading article, similar discourses were also detected in the students' reflections. In addition to the fertility discourse and the media representation/effect discourse, the adoption discourse was found in some student reflections as a response to the biological son discourse. The adoption discourse can be regarded as an oppositional discourse against the fertility discourse because it resists the taken-for-granted idea inherent in the biological son discourse, which is part of the fertility discourse.

If we classify the above discourses in terms of whether they perpetuate the status quo or they challenge it and call it into question, we can categorize these discourses into two blanket discourses: the conservative discourse and the liberatory discourse. Under the category of conservative discourse are grouped the fertility discourse, the biological son discourse and the fertility technology discourse, and under the category of liberatory discourse are grouped the media representation/effect discourse and the adoption discourse. The categorization is shown in Figure 5.

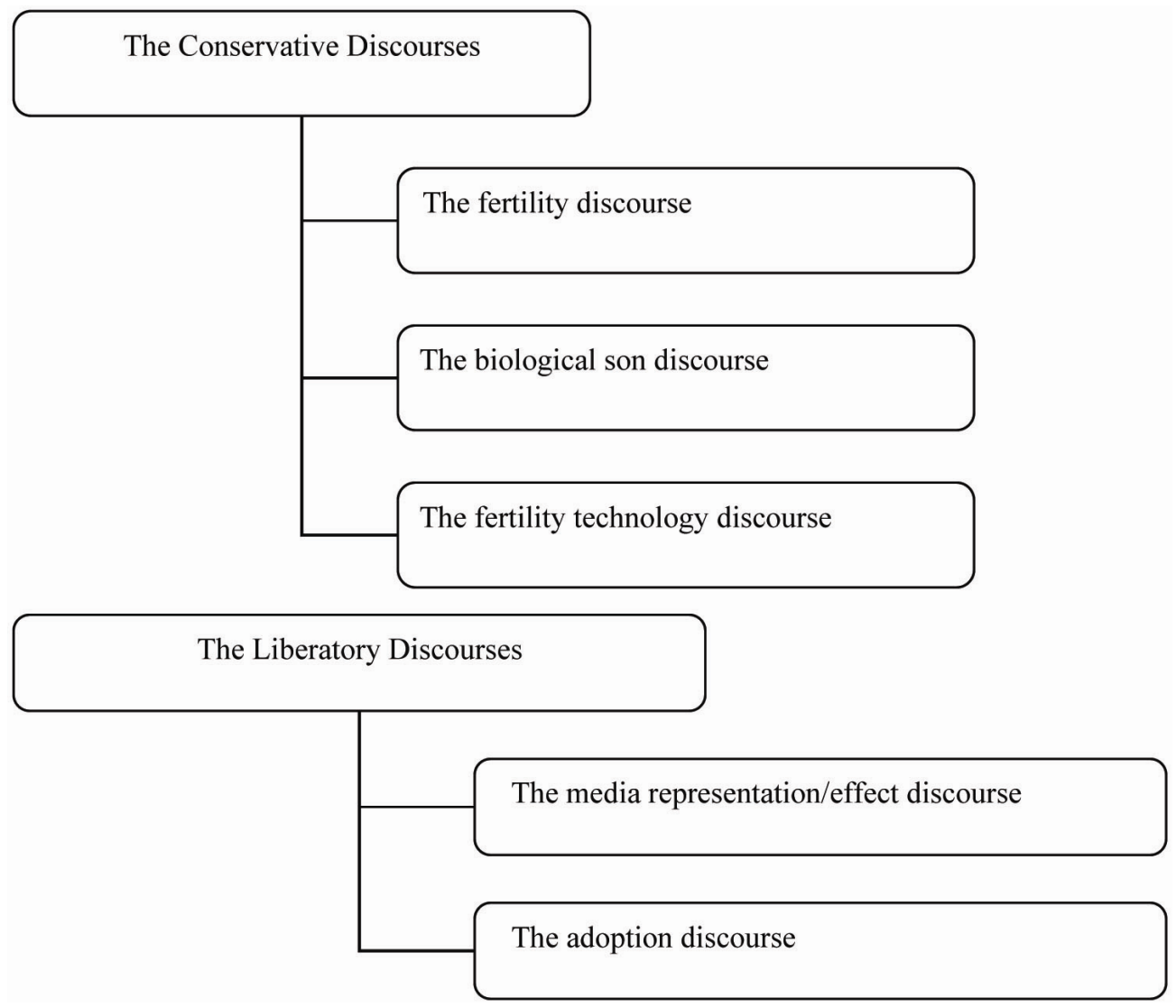

Figure 5. Discourses in Students' Reflections on "Eight Is Too Many" 


\subsubsection{Conservative Discourse}

\section{(1) The fertility discourse}

The fertility discourse is conservative in nature because it reproduces the traditional idea that married couples should raise their biological offspring. In other words, both husband and wife are supposed to be fertile, and this concept goes with another common belief that the more offspring the married couples have, the more prosperous their family will be. This kind of discourse is articulated in several student reflections; however, after they read this article, the grip of this discourse seemed to become loosened:

I have once seen the TV broadcasting the news about a mother giving birth to a set of quintuplets. At that time, seeing the joy of the parents, I was also happy. However, after reading this article, I may feel more worried for them than happy now. There is a Chinese saying says, "More offspring you get, more good fortune you have;" but this saying seems to be rewrote as "more offspring you get 'at once,' more 'bad fortune' you have." (S3, reflection)

In another student's reflection, the fertility discourse that "more offspring you get, more good fortune you have" is articulated. But the idea of raising more children in the family now seems to be, not a blessing, but a burden:

After I read this article, I was so surprised that what we always admire for having so many babies at one time is actually a serious trouble. In the old era, women were expected to give births as many as they can. It was so common that a family had more than four children in my grandmother's generation. Every family believed the more offspring you had, the more luck or money you had. (S5, reflection)

(2) The biological son discourse

The biological son discourse has a strong impact on Taiwanese people because many of them still hold the traditional Chinese concept that one of the main functions of marriage is to continue the family name, which means they must have a biological son to perpetuate their family name. In other words, in order to carry on the pure blood of the family line, the married couple must raise a son and this son must be their own flesh and blood. This discourse is given expression in a Confucian saying which goes: "Having no descendants is the most serious of the three cardinal violations of filial piety." One student, though admitting that this idea is old and perhaps behind the times, articulates this discourse in her reflection:

Although our society has become less traditional, there are still something very traditional. People think it is very important to have a marriage between families of equal social rank. Moreover, older people insist in having a son to carry on the family line. These old thoughts are still very deep in everybody's mind. (S16, reflection)

(3) The fertility technology discourse

The biological son discourse explains why so many infertile couples are desperate to seek help from modern reproductive technologies. It is easy to see the close connection between the biological son discourse and the fertility technology discourse which is the attempt to intervene in the natural condition, in this case, to intervene in the condition of infertility through modern technology. Like other technology discourses, the fertility technology discourse holds two views of what technology can do to us; namely, the utopian view and the dystopian view. On one hand, the utopian view holds that technology is a panacea for all the problems of humankind, thus bringing us boundless hope and immeasurable happiness; on the other hand, the dystopian view holds that technology can grow out of its inventor's control and consequently brings humankind unimaginable catastrophes like the Frankenstein tale created by the romantic novelist, Mary Shelly. In student reflections both views of technology are detected; that is to say, the technology can work wonders for people but at the same time it also brings disaster and suffering to them when misused. The utopian discourse of fertility can be seen in the following student reflections:

But after I finish reading this quite long article, I understand that such a miracle was all thanks to the modern reproductive technologies. The modern technology has indeed brought the hope and the miracle to many infertile couples. (S33, reflection)

Fertility technology sometimes brings about things that were not originally expected. When this happens, people attribute the results to the misuse of technology and come up with the dystopian technology discourse. Most of the students reading about the fertility technology that inadvertently produced septuplets or octuplets held the dystopian view of technology. The following reflection, though admitting the benefits of technology, voices the dystopian aspect of technology: 
The modern technologies help many infertile couples to have kids. But when the problems which I just mentioned about happened, the fertility technology became a misuse; not a wonderful thing anymore, but became an error. For example, many of these multiple infants have to suffer pain while they just arrived in this world. Or some of them died after birth. Is this a miracle or a disaster? So in my opinion, new technologies did bring more convenient lives, but if we misuse it, then it will be an irretrievable tragedy. (S12, reflection)

\subsubsection{Liberatory Discourse}

(1) The media representation/ effect discourse

The media representation discourse shows how the media influence the understanding and, subsequently, behavior of viewers through a selective representation of a given event. Since the media representation is often manipulated by the government or other powerful organization to control people, they thus tend to sustain the status quo by presenting mainstream beliefs or prevalent ideas in society. Therefore, when students resist the partial, sometimes false, representation of an event in the news media in their reflections, they produce the media representation/ effect discourse. The media representation/ effect discourse is considered liberatory because it resists the brainwashing caused by the media representation. One student reflected on the situation of the media in Taiwan, producing a discourse that shows her critical awareness that the representation in the media is partial and purpose-oriented with a view to influencing its viewers:

In Taiwan, the media often broadcast news that is sensational or beneficial to television broadcasting station. Therefore, sometimes we are brainwashed by these not exactly correct news. (S19, reflection)

Another student expressed the brainwashing effect of the media representation of multiple births in his reflection, saying "people are easily misled" by it:

Because media always like to excessively report multiple births. Whenever we watched news about the multiple births, the reporter describes the multiple births as a wonder or a miracle. People are easily misled by the glorifying news. (S36, reflection)

Closely related to the media representation discourse is the media effect discourse. The following discourse articulated by a student demonstrates the student's raised consciousness of the effect of the media:

Nowadays, our society is media-saturated. As soon as being interviewed or broadcasted, people will get abundant attention and become the talking point. In Taiwan, the situation is the same. Everyday the TVs are broadcasting news about poor people who do not have any money to keep living. After the news, abundant supply and donations will spring up. At the same time, is there anybody who knows where these donations really go to? (S10, reflection)

(2) The adoption discourse

The adoption discourse liberates infertile couples from the domination of the fertility discourse which holds that married couple should be fertile and bear children, thus fulfilling the sanctified mission of continuing the family name. To continue the family name in the Chinese tradition means to have a biological son. The fertility discourse explains why so many infertile couples in the Chinese society would try any medical method or do anything to produce a son. It also explains why boys are always privileged over girls in the Chinese society. However, this time-honored idea held in the fertility discourse is contested and deconstructed by the adoption discourse, and it can thus be viewed as a counter discourse against the hegemony of the fertility discourse and its related biological son discourse.

The fertility discourse is a socio-cultural construct which views the continuation of life, that is, one's lineage, in terms of individual lives, that is, a biological son. The adoption discourse challenges this narrow view of the continuation of life by broadening the concept of lineage to that which belongs to all humanity. Thus the adoption discourse dispels the myth that only your biological son can continue your family name. Instead the adoption discourse holds that one's family name can be continued by any son because the concept of one's family narrowly defined as belonging to individuals is broadened to that of all humanity. Several students produced the adoption discourse as a solution to the problem of infertility in their reflections. The following is a student's reflection that shows her acceptance of the adoption discourse when facing the problem of infertility:

For me, I would rather adopt children who really need help or just have no baby instead of great frustration during pregnancy and delivery or a bunch of unhealthy and troublesome babies. (S11, reflection)

Other students see adoption not only as a practice that solves infertile couples' problems, but also as a practice that relieves the social problems caused by abandoned children: 
In my opinion, since infertility insemination causes so many problems, it would be better to adopt children. Infertile couples can not only fulfill the dream of having children but also release social problems. I do believe that they can treat the foster children as their own with their whole hearts.

(S25, reflection)

When deep-rooted discourses are challenged or called into question, people have a chance to re-examine them from a new perspective. New perspectives help us see things critically and understand the things that we used to believe as true or natural are no more than a social and cultural construct. These naturalized concepts are taught to us through the process of socialization and become established as part of life and culture. To think differently is to engage in what Shor (1992) called a form of "desocialized thinking." De-socialization leads to critical consciousness, which in turn destabilizes the deep-rooted and taken-for-granted ideas in society. The destabilization that is made possible by the critical consciousness of individuals will also make social transformation possible. The grip of the fertility discourse is loosened when students are able to free themselves from the socialized and habitual mode of thinking and produce an oppositional discourse against the conventional, taken-for-granted discourse. In this case it is the adoption discourse that will destabilize the fertility discourse, or more specifically, the biological son discourse. A raised consciousness of the adoption discourse leads to a new, liberating social practice. However, some deep-rooted beliefs are difficult to change even though society has become less traditional. The following reflection shows one student's awareness that old concepts should be changed before new social practices can happen:

In these years, adopting children has become more acceptable. However, in the past, people thought the adopted children could not get along with the parents very well. Therefore, a lot of people refused to adopt children. As a result, I think our society has become less traditional, but the deep of our mind has not changed yet. (S14, reflection)

\section{Summary, Discussion and Conclusion}

Drawing on Fairclough's concept of the dialectical relationship between discourse and society (1992a), the analysis of the students' post-reading reflections revealed that their critical literacy was developed. Prior to the critical literacy instruction, critical consciousness was not found in most of the students' reflections. In their response to the pre-instruction reading article "Mother's Camp," almost all of the students articulated the conservative motherhood discourse, assuming the taken-for-granted responsibilities of a wife and mother and that mothers certainly deserved a getaway, i.e. the mother's camp, to refresh themselves. Only one student resisted the gender stereotyping implied in the motherhood discourse.

However, as the course went on, the students were able to display more and more egalitarian or liberatory discourses in their reflections though there were still many students reproducing conservative discourses. In their response to "Families Grow Less Traditional," around one-third of the students articulated egalitarian discourse, which challenge the taken-for-granted ideas about gender differences, call into question the idea that the traditional family is the norm, and welcome the idea of diversity and admit of different ways of being in this world such as gay families. But some students still articulated conservative discourses, which privilege traditional families as the norm, emphasize the status quo, and hence disapprove of other ways of being in the world.

And in their response to the article, "Eight Is Too Many," more than one-third students displayed the liberatory discourse in their reflections such as the media representation/effect discourse and the adoption discourse. In media representation/effect discourse, students were aware of how the media influenced the understanding and subsequently behavior of audience through a selective representation of a given event. In the adoption discourse, students resisted the taken-for-granted ideas inherent in the biological-son discourse and thus liberated infertile couples from the domination of the fertility discourse which holds that married couples should be fertile and bear children. However, some students still articulated the conservative discourse, holding the traditional idea that married couples should raise their biological offspring and therefore technological intervention is needed to enable biological offspring for infertile couples.

The egalitarian or liberatory discourses in the students' reflections are considered emancipatory in that they will empower students to bring about social change for a more democratic and equitable society because what students think or believe affects their actions in the future. In other words, when students produced an emancipatory discourse in their reflections on the texts they read, they had a corresponding change in their ways of seeing the world. When students are able to produce a discourse different from the one they used to hold, then change has happened in their consciousness. This change also indicates a different social practice for them, which in turn brings about different social structure. As pointed out by Janks (2012), "While the social constructs who we are, so do we construct the 
social. The dialectic relationship is fluid and dynamic, creating possibilities for social action and change" (p. 151). In other words, social transformation is made possible by changing individuals' consciousness.

To sum up, three conclusions can be made for the present study: First, it is important to incorporate critical literacy into the EFL reading curriculum because comprehension is no longer viewed as merely understanding the literal meaning of a text; more importantly, comprehension of a text is aimed at understanding the discourse meaning of a text, i.e., social and political meanings that make the text meaningful in its context of use. Therefore, the ultimate goal of teaching reading in the EFL context lies not merely in teaching students the language skills which they can use for future communicative purposes but also in teaching them how they can critically use language in their everyday life.

Second, EFL teachers in a critical literacy reading class should help students not only "read the word," but encourage them to "read the world" as well (Freire \& Macedo, 1987; Ko \& Wang, 2009). Only by "reading the world" will students become aware that learning and using a language is a social practice situated in the real world and that "language-in-use is everywhere and is always political" (Gee, 1999, p.1).

Third, critical literacy foreign language instruction can empower students through raising students' consciousness of the oppressive social structure and help them understand the power of agency deriving from critical consciousness, thus bringing about the social changes needed for a more democratic and equitable society.

\section{References}

Althusser, L. (1971). Ideology and ideological state apparatuses. In L. Althusser (Ed.), Lenin and philosophy and other essays (pp. 137-177). London: New Left Books.

Auerbach, E. R. (1995). The politics of the ESL classroom: Issues of power in pedagogical choices. In J. Tollefson (Ed.), Power and inequality in language education (pp. 9-33). Cambridge University Press.

Cervetti, G., Pardales, M. J., \& Damico, J. S. (2001). A tale of differences: Comparing the traditions, perspectives, and educational goals of critical reading and critical literacy. Reading Online, 4 (9). [Online] Available: http://www.readingonline.org/articles/cervetti

Crookes, G., \& Lehner, A. (1998). Aspects of process in an ESL critical pedagogy teacher education course. TESOL Quarterly, 32, 319-328. http://dx.doi.org/10.2307/3587586

Fairclough, N. (1992a). (Ed.) Critical Language Awareness. New York: Longman.

Fairclough, N. (1992b). Discourse and social change. Cambridge: Polity Press.

Freire, P., \& Macedo, D. (1987). Literacy: Reading the word and the world. London: Routledge \& Kegan Press

Gee, J. P. (1990). Social linguistics and literacies: Ideology in discourses. London: Falmer.

Gee, J. P. (1999). An introduction to discourse analysis: Theory and Method. London: Routledge.

Giroux, H. A. (1992). Border crossings: Cultural workers and the politics of education. New York: Routledge.

Gramsci, A. (1991). Selections from prison notebooks. London: Lawrence and Wishart

Halliday, M. A. K. (1973). Exploration in the functions of language. London: Edward Arnold.

Halliday, M. A. K. (1978). Language as a social semiotic: The social interpretation of language and meaning. London: Edward Arnold

Huang, S. Y. (2011a). "Critical literacy helps wipe away the dirt on our glasses": Towards an understanding of reading as ideological practice. English Teaching Practice and Critique, 10 (1), 140-164. [Online] Available: http://edlinked.soe.waikato.ac.nz/research/journal/view.php?article=true\&id=695\&p=1

Huang, S. Y. (2011b). Reading "Further and beyond the text": Student perspectives of critical literacy in EFL reading and writing. Journal of Adolescent \& Adult Literacy, 55, 145-154. http://dx.doi.org/10.1002/JAAL.00017

Janks, H. (2012). The importance of critical literacy. English Teaching: Practice and Critique, 11(1), 150-163. [Online] Available: http://edlinked.soe.waikato.ac.nz/research/journal/view.php?article=true\&id=788\&p=1

Jorgensen, M., \& Phillips, L. (2002). Discourse analysis. London: Sage.

Ko, M. (2013). A case study of an EFL teacher's critical literacy teaching in a reading class in Taiwan. Language Teaching Research, 17, 91-108. http://dx.doi.org/10.1177/1362168812457537 
Ko, M., \& Wang, T. F. (2009). Introducing critical literacy to EFL teaching: Three Taiwanese college teachers' conceptualization. Asian EFL Journal, 11, 1, 174-191.

Ko, M., \& Wang, T. F. (2012a). Critical literacy-based writing instruction in EFL contexts: Exploring social issues. Providence Forum: Language and Humanities, 5 (2), 1-33.

Ko, M., \& Wang, T. F. (2012b). EFL learners' critical literacy practices: A case study of four college students in Taiwan. The Asia-pacific Education Researcher. http://dx.doi.org/ 10.1007/s40299-012-0013-5 (Online First, 13 September 2012).

Kuo, J. M. (2009). Critical literacy and a picture-book-based dialogue activity in Taiwan. Asia Pacific Education Review, 10, 483-494. http://dx.doi.org/10.1007/s12564-009-9048-6

Morgan, B. (1998). The ESL classroom: Teaching, critical practice, and community development. Toronto: University of Toronto.

Norton, B., \& Toohey, K. (2004). Critical pedagogies and language learning. Cambridge University Press. http://dx.doi.org/10.1017/CBO9781139524834

Okazaki, T. (2005). Critical consciousness and critical language teaching. Second Language Studies, 23 (2), 174-202.

Pennycook, A. (1999). Introduction: Critical approaches to TESOL. TESOL Quarterly, 33, 329-348. http://dx.doi.org/10.2307/3587668

Pennycook, A. (2001). Critical applied linguistics: A critical introduction. Mahwah, NU: Lawrence Erlbaum Associated.

Ramanathan, V. (2002). The politics of TESOL education. New York: Routledge Falmer/Taylor \& Francis.

Shor, I. (1992). Empowering education: Critical teaching for social change. London: University of Chicago Press.

Sunderland, J. (2004). Gendered discourses. New York: Palgrave MacMillan. http://dx.doi.org/10.1057/9780230505582 